\title{
CLUSTER ANALYSIS OF MULTICRITERIA-CLASSIFIED WHEELED ARMORED VEHICLES
}

\author{
KEREKES HARCJÁRMÜVEK TÖBBSZEMPONTÚ ÉRTÉKELÉSÉNEK \\ KLASZTERANALÍZISE
}

\author{
GÁVAY, György; TÓTH, Bence \\ (ORCID: 0000-0003-0632-5650); (ORCID: 0000-0003-3958-187X) \\ gavay.gyorgy@uni-nke.hu; toth.bence@uni-nke.hu
}

\begin{abstract}
Cluster analysis was performed on the data representing the defense of 32 wheeled armored vehicles based on a Multi Criteria Decision Support model. The number of clusters was determined by nonhierarchical clustering, while the vehicles were assigned to a cluster by non-hierarchical clustering. The number of clusters are either three or eight. For three assumed clusters, the BTR-type, the equipment designed before and after 2000 were grouped together, while for eight assumed clusters, these groups split into subgroups. Each subgroup consist of vehicles with similar defense, while the distinction between the subgroups could be made on the basis of modernization, the evolution of defense techniques in time.
\end{abstract}

Keywords: clustering, cluster analysis, k-means, GAIA, wheeled armored vehicle

\begin{abstract}
Absztrakt
Harminckét kerekes harcjármüvet jellemzö, többszempontú döntéshozatali modell alapján kapott, a jármüvek védettségét leíró adatokon végeztünk klaszteranalízist. Hierarchikus módszerrel meghatároztuk a klaszterek számát, majd nemhierarchikus módszerrel az egyes klaszterek tagjait. A klaszterek lehetséges számára három és nyolc adódott. Három feltételezett klaszter esetén a BTR típusú, a 2000 elött, illetve után tervezett harcjármüvek alkottak egy-egy csoportot, míg nyolc feltételezett klaszter esetén ezen három csoport részhalmazai alkottak egy-egy alcsoportot. Az alcsoportok közel azonos védettségü harcjármüveket tartalmaztak, míg az egyes csoportok között a védelem módjainak időbeli fejlődése, a modernizáció volt a legalapvetöbb különbség.
\end{abstract}

Kulcsszavak: klaszteranalizis, k-közép, GAIA, kerekes harcjármü 


\section{INTRODUCTION}

The comparison, evaluation and ranking of armaments, and especially military equipment is an ever important task for every army [1][2]. Theoretical and practical analyses play an important role in the acquisition of wheeled armored vehicles which means the evaluation and the choosing from possible alternatives on the basis of several different criteria [3][4]. Proper Multi Criteria Decision Making (MCDM) models [5] give support for the theoretical analysis: with their help, the alternative choices can be ranked and their similarities and dissimilarities can be detected on the basis of a given set of criteria [6].

Furthermore, the results obtained by one method can be analyzed by another method, too. This paper presents the cluster analysis of previous results [7] obtained by an MCDM model using the Visual PROMETHEE software [8]. This method has already been proved to be a sufficient tool for analyzing military equipment [9] The authors hope, that it can be utilized in the future in the field of comparative analysis of military equipment and military vehicles [10][11].

\section{METHODS}

\section{The PROMETHEE and GAIA methods}

The data analyzed in this study was obtained by the PROMETHEE and the GAIA methods, which are described in detail in [12]. The GAIA method can visualize the alternatives and the criteria for the evaluation of the data processed the PROMETHEE model [12;pp.49-69].

The PROMETHEE method is capable to compare and rank a high number of alternatives. The aim of our recent research, the results of which are used as the initial data of this study, was to compare and rank a total of 32 Armored Personnel Carriers (APC) and Infantry Fighting Vehicles (IFV).

At first, each criterion has to be weighted regarding its importance in the decision to be made. This is the most vital, and also the hardest task to do, and it is based on the knowledge and experience of the decision maker. If done properly, not only the optimal choice from the alternatives but also the order between the alternatives can be obtained. The sum of the weights has to be 1 .

Then, each alternative is described by a real number in the light of every criterion. By taking the weights into account, this results in having a 30-dimensional vector describing each alternative. To compare the alternatives, these vectors are projected from the 30-dimensional Euclidean space into a two-dimensional plane called GAIA-plane. This is carried out to lose as little information as possible, though some is inevitable. The difference between the original and the projected vectors can also be described by a vector, $\boldsymbol{\delta}_{j}$, for each alternative $(1 \leq j \leq 32)$.

The PROMETHEE method makes projection to minimize the sum of the $\boldsymbol{\delta}_{j} \boldsymbol{\delta}_{j}$ dot products for all 32 alternatives and thus to minimize the information loss. [12;pp.67-72] In this way, in general, if the two-dimensional projections are close to each other, the original 30-dimensional vectors were also close to each other and thus the alternatives are similar.

The projection also shows how important a criterion is: if its unity vector lies close to the center of the GAIA-plane, which means that it was nearly perpendicular to the projection, then it has no significant effect on the decision to be made. On the contrary, a long projection of a criterion vector means that the criterion is important.

The sum of the weights of the criteria in the 30-dimensional criteria space, the weight vector, is called the Decision Stick (marked with $\boldsymbol{\pi}$ in Fig. 1) and is also projected to the GAIA-plane. 


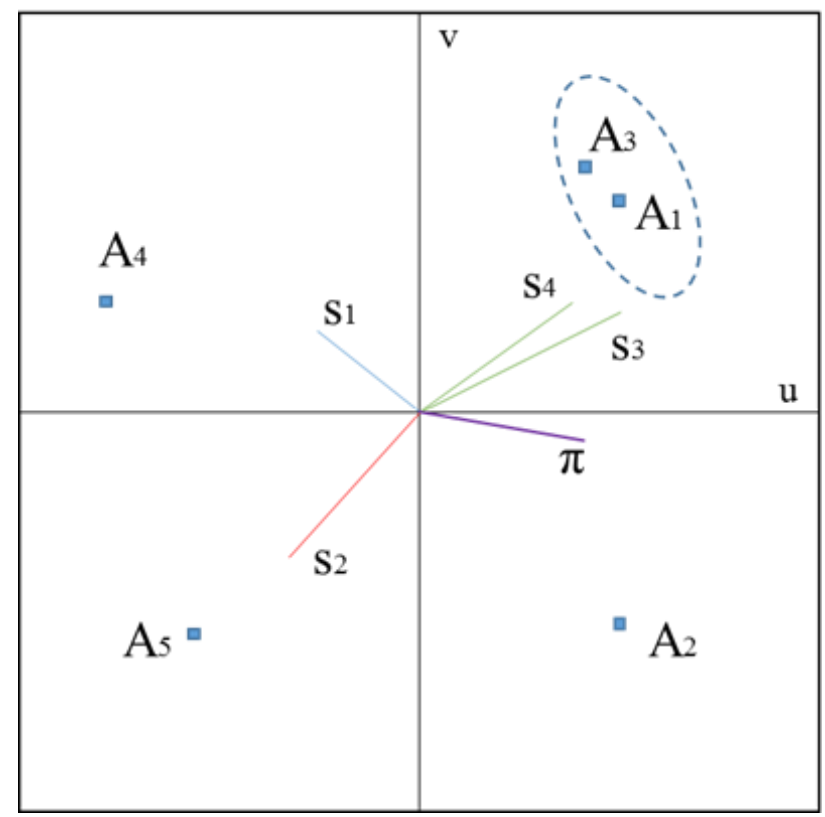

Figure 1. Example showing the projection of criterion vectors, alternatives and the Decision Stick on the GAIA plane. (Made by authors using [12].)

From the GAIA plane, the following information can be deduced:

- criteria with approximately parallel vectors can be satisfied simultaneously by the given alternatives,

- if two criteria are independent, they are represented by perpendicular vectors,

- two criteria, with vectors pointing in opposite directions cannot be satisfied simultaneously,

- the length of a criterion vector represents the distinctive power of the given criterion,

- alternatives closer to a vector mean a better choice in fulfilling that criterion, while alternatives farther mean a worse choice.

Two planes were used according to two applications area: the suitability for areal defense (AD) and the applicability in (abroad) mission field (MF). As a result, two full PROMETHEE rankings (Table1) and two GAIA planes were obtained. The criteria used for each application can be seen in Figure2. The red vector is the Decision Stick. 

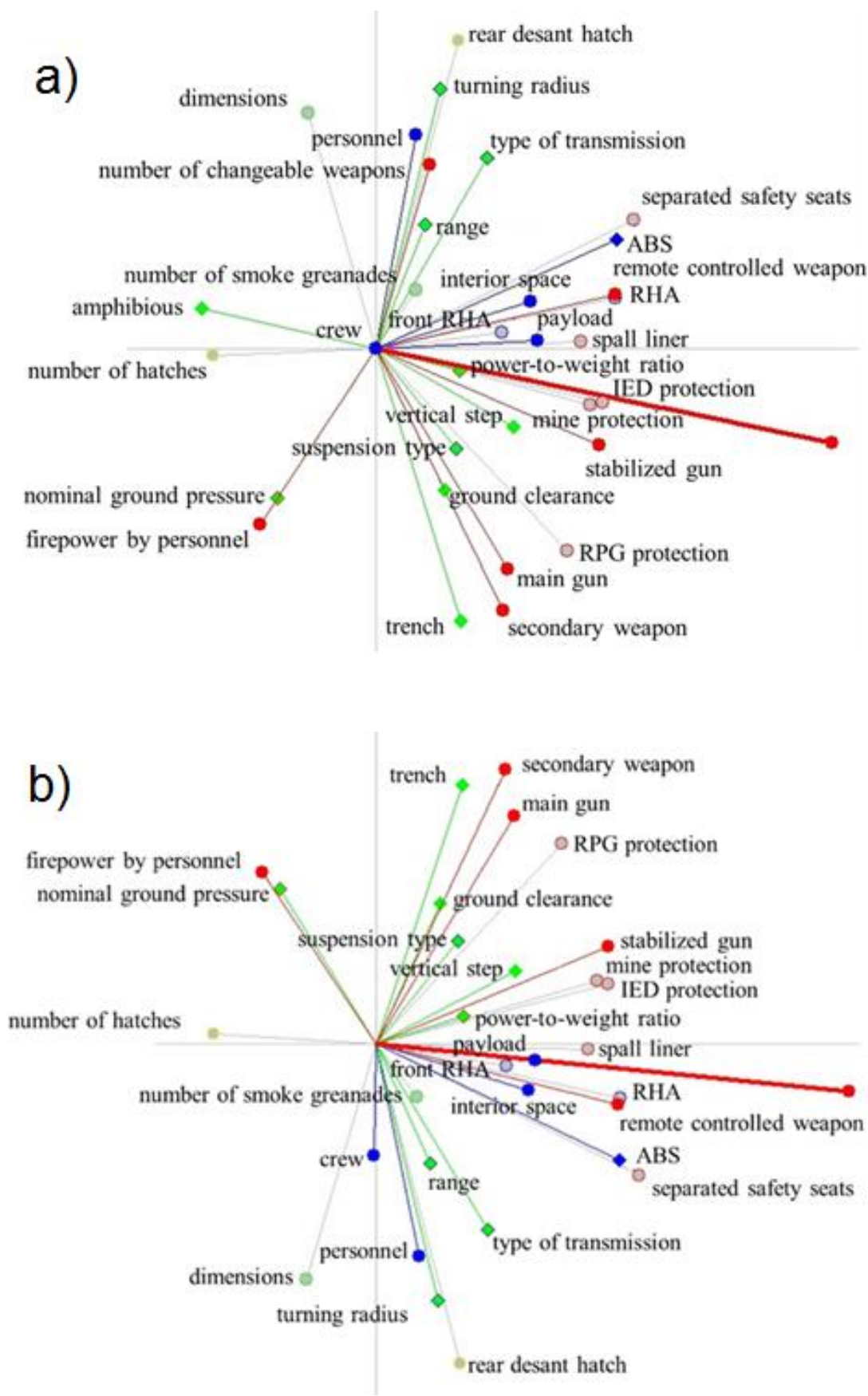

Figure 2. Visualization of the criteria on the GAIA plane for the a) AD and the b) MF applications. The Decision Stick is indicated by the thick red line. (Made by authors.) 


\begin{tabular}{|l|l|l|l|l|}
\hline AD & alternative & Phi & Phi+ & Phi- \\
\hline 1 & Patria AMV xp & 0.2692 & 0.3085 & 0.0393 \\
\hline 2 & Patria AMV & 0.2677 & 0.3032 & 0.0355 \\
\hline 3 & Patria AMV_XC360P & 0.2572 & 0.2977 & 0.0405 \\
\hline 4 & Piranha 5 & 0.2455 & 0.2908 & 0.0453 \\
\hline 5 & Pandur_II 8x8 & 0.2287 & 0.2799 & 0.0511 \\
\hline 6 & VBCI_I & 0.2144 & 0.2641 & 0.0497 \\
\hline 7 & VBCI_II & 0.2092 & 0.2685 & 0.0593 \\
\hline 8 & FSNN 8x8 & 0.1924 & 0.2285 & 0.0361 \\
\hline 9 & Boxer IFV & 0.1533 & 0.2761 & 0.1228 \\
\hline 10 & Pandur_II 6x6 & 0.1461 & 0.2214 & 0.0753 \\
\hline 11 & VAB_III & 0.1388 & 0.2251 & 0.0863 \\
\hline 12 & VAB_II & 0.1339 & 0.2087 & 0.0748 \\
\hline 13 & Ejder & 0.1261 & 0.188 & 0.0619 \\
\hline 14 & FSNN 6x6 & 0.0943 & 0.1653 & 0.071 \\
\hline 15 & BTR 90 & 0.0717 & 0.2556 & 0.1839 \\
\hline 16 & Boxer APC & 0.065 & 0.2136 & 0.1486 \\
\hline 17 & Stryker DVH & 0.0047 & 0.1656 & 0.1608 \\
\hline 18 & LAV25 & 0.0008 & 0.1822 & 0.1814 \\
\hline 19 & M1117 TAPV & -0.0314 & 0.15 & 0.1814 \\
\hline 20 & Fuchs_II & -0.0481 & 0.1618 & 0.2099 \\
\hline 21 & BTR 82A & -0.0494 & 0.1963 & 0.2457 \\
\hline 22 & Patria XA185 & -0.08 & 0.1419 & 0.2218 \\
\hline 23 & VAB NG & -0.1986 & 0.1144 & 0.313 \\
\hline 24 & Fuchs_A8 & -0.204 & 0.1137 & 0.3178 \\
\hline 25 & Piranha III & -0.2061 & 0.0905 & 0.2967 \\
\hline 26 & BTR 80A & -0.235 & 0.1402 & 0.3752 \\
\hline 27 & Pandur_I & -0.2513 & 0.0906 & 0.3418 \\
\hline 28 & Patria XA202 & -0.2673 & 0.0675 & 0.3348 \\
\hline 29 & VAB_I & -0.2788 & 0.0936 & 0.3724 \\
\hline 30 & M1117 ASV & -0.3153 & 0.0387 & 0.3539 \\
\hline 31 & Fuchs_I & -0.3249 & 0.0585 & 0.3834 \\
\hline 32 & BTR 80 & -0.329 & 0.0825 & 0.4115 \\
\hline & & & \\
\hline
\end{tabular}

\begin{tabular}{|l|l|l|l|l|}
\hline MF & alternative & Phi & Phi+ & Phi- \\
\hline 1 & Patria AMV_XC360P & 0.2279 & 0.2733 & 0.0454 \\
\hline 2 & Pandur_II 8x8 & 0.2145 & 0.2658 & 0.0513 \\
\hline 3 & Pandur_II 6x6 & 0.2119 & 0.2755 & 0.0636 \\
\hline 4 & Patria AMV & 0.2097 & 0.2687 & 0.059 \\
\hline 5 & Patria AMV xp & 0.2089 & 0.269 & 0.0601 \\
\hline 6 & Piranha 5 & 0.2 & 0.2574 & 0.0574 \\
\hline 7 & VBCI_I & 0.1831 & 0.235 & 0.0519 \\
\hline 8 & FSNN 8x8 & 0.179 & 0.2302 & 0.0511 \\
\hline 9 & VBCI_II & 0.1583 & 0.2359 & 0.0776 \\
\hline 10 & VAB_II & 0.1524 & 0.2224 & 0.07 \\
\hline 11 & Boxer APC & 0.1392 & 0.2414 & 0.1022 \\
\hline 12 & Ejder & 0.1387 & 0.2086 & 0.07 \\
\hline 13 & Boxer IFV & 0.1211 & 0.2631 & 0.142 \\
\hline 14 & VAB_III & 0.1129 & 0.1968 & 0.0839 \\
\hline 15 & FSNN 6x6 & 0.0716 & 0.1624 & 0.0908 \\
\hline 16 & Stryker DVH & 0.0487 & 0.1718 & 0.1231 \\
\hline 17 & BTR 90 & 0.0145 & 0.2363 & 0.2218 \\
\hline 18 & Fuchs_II & -0.014 & 0.154 & 0.168 \\
\hline 19 & LAV25 & -0.0418 & 0.1733 & 0.2151 \\
\hline 20 & M1117 TAPV & -0.064 & 0.1439 & 0.2079 \\
\hline 21 & VAB NG & -0.1235 & 0.1467 & 0.2702 \\
\hline 22 & BTR 82A & -0.1267 & 0.1697 & 0.2964 \\
\hline 23 & Piranha III & -0.1291 & 0.1108 & 0.2399 \\
\hline 24 & Patria XA185 & -0.1504 & 0.1267 & 0.2772 \\
\hline 25 & Fuchs_A8 & -0.1695 & 0.128 & 0.2975 \\
\hline 26 & Pandur_I & -0.1782 & 0.1277 & 0.3059 \\
\hline 27 & VAB_I & -0.1794 & 0.1328 & 0.3122 \\
\hline 28 & M1117 ASV & -0.26 & 0.0492 & 0.3092 \\
\hline 29 & Patria XA202 & -0.2806 & 0.0838 & 0.3643 \\
\hline 30 & Fuchs_I & -0.2888 & 0.0696 & 0.3584 \\
\hline 31 & BTR 80 & -0.2911 & 0.1006 & 0.3917 \\
\hline 32 & BTR 80A & -0.2953 & 0.1212 & 0.4165 \\
\hline & & &
\end{tabular}

Table 1. The PROMETHEE ranking of equipment in the AD and MF applications. (Made by authors from the results of Visual PROMETHEE Academic Free Edition ${ }^{1}$ [13][14].)

\section{Clustering methods}

To determine the clusters of data points, two types of clustering have to be carried out: first, a hierarchical clustering to obtain the number of clusters and then a non-hierarchical one to get the exact elements of the clusters. All of the clustering was carried out in the R programming language and environment [15].

\footnotetext{
${ }^{1}$ The Visual PROMETHEE Academic Edition is fully functional without any limits. It is available for free for non-profit research and teaching only.
} 


\section{Hierarchical clustering}

For the hierarchical clustering, agglomerative methods were used. These methods start with as many clusters as data points: each data point is one cluster. The distance between each pair of clusters is determined and the two clusters with minimal distance are merged into a new cluster. Then the distances between the new clusters are determined again, and the two with minimal distance are merged again and this process goes on until every data point belongs to one cluster. This means that in each step the number of clusters decreases by one and there are $(N-1)$ steps in the clustering process.

The hierarchical clustering was carried out by using the hclust() function of the built-in stats package [15] of R. The methods selected to determine the distance between clusters were:

- the Single Linkage Method,

- the Complete Linkage Method,

- the Average Linkage Method (also known as UPGMA, Unweighted Pair Group Method with Arithmetic averaging) and

- the McQuitty Method (or WPGMA, Weighted Pair Group Method with Arithmetic averaging).

The selection was made to ensure that at each step the distance measure increases and thus a sudden increase in the minimal distance of the two clusters merged in the $m$ th step is a sign of having reached the optimal number of clusters in the $(m-1)$ th step. In other words, denoting the distance between the two closest clusters in the $m$ th step by $\ell_{m}$, if $\ell_{m}-\ell_{m-1} \gg \ell_{m-1}-\ell_{m-2}$, then the optimal number of clusters is $(m-1)$.

There are several possible metrics to use to determine the distance. In this study, the most common one, the Euclidean distance was used.

The clustering methods differ in how they calculate the distance of two clusters at least one of which contain more than one element. To demonstrate these differences, let $a=(A B)$ denote the cluster of data points $A$ and $B,(C(A B))$ or $((A B) C)$ denote the merged cluster of $(A B)$ and data point $C$. The distance between data points $A$ and $B$, between clusters $(A B)$ and $(C D)$ and between cluster $(A B)$ and data point $C$ will be denoted by $\ell_{A, B}, \ell_{(A B),(C D)}$ and $\ell_{(A B), C}$, respectively. The mean value of the coordinates of the data points in cluster $a$, called centroid, is denoted by $\bar{a}$ and for a merged $a b$ cluster by $\overline{a b}$. The distances calculated by each method is summarized in Table 1. [8] 


\begin{tabular}{|l|l|}
\hline Method & Distance between two clusters \\
\hline $\begin{array}{l}\text { Single } \\
\text { Linkage }\end{array}$ & $\begin{array}{l}\text { The distance between the closest elements of the two clusters. } \\
\ell_{(A B), F}=\min \left(\ell_{A, F}, \ell_{B, F}\right) \\
\ell_{(A B), C D)}=\min \left(\ell_{A, C}, \ell_{A, D}, \ell_{B, C}, \ell_{B, D}\right)\end{array}$ \\
\hline $\begin{array}{l}\text { Complete } \\
\text { Linkage }\end{array}$ & $\begin{array}{l}\text { The distance between the farthest elements of the two clusters. } \\
\ell_{(A B), F}=\max \left(\ell_{A, F}, \ell_{B, F}\right) \\
\ell_{(A B), C D)}=\max \left(\ell_{A, C}, \ell_{A, D}, \ell_{B, C}, \ell_{B, D}\right)\end{array}$ \\
\hline $\begin{array}{l}\text { Average } \\
\text { Linkage } \\
\text { (UPGMA) } \\
\text { The average of the pairwise distances between all of the elements of the two } \\
\text { clusters regardless of the previous steps of clustering. } \\
\ell_{(A B), F}=\left(\ell_{A, F}+\ell_{B, F}\right) / 2 \\
\ell_{(A B), C D)}=\left(\ell_{A, C}+\ell_{A, D}+\ell_{B, C}+\ell_{B, D}\right) / 4 \\
\ell_{(E(A B)), F}=\left(\ell_{A, F}+\ell_{B, F}+\ell_{C, F}\right) / 3\end{array}$ \\
McQuitty & $\begin{array}{l}\text { The average of the pairwise distances between all of the elements of the two } \\
\text { clusters taking into account the previous steps of clustering. } \\
\ell_{(A B), F}=\left(\ell_{A, F}+\ell_{B, F}\right) / 2 \\
\ell_{(A B), C D)}=\left(\left(\ell_{A, C}+\ell_{A, D}\right) / 2+\left(\ell_{B, C}+\ell_{B, D}\right) / 2\right) / 2=\left(\ell_{A, C D)}+\ell_{B,(C D)}\right) / 2 \\
\ell_{(E(A B), F}=\left(\left(\ell_{A, F}+\ell_{B, F}\right) / 2+\ell_{C, F} / 2=\left(\ell_{(A B), F}+\ell_{E, F}\right) / 2\right.\end{array}$ \\
\hline
\end{tabular}

Table 2. The calculation of the distance of two clusters by each criterion (made by authors)

\section{Non-hierarchical clustering}

Knowing the number of expected clusters from the hierarchical method(s), non-hierarchical clustering can be carried out to determine the members of each cluster. For this purpose, the so-called $k$-means clustering will be used. A metric is also needed, with which the distances are determined, for which the Euclidean distance was used.

First, $k$ so-called centroid points are randomly selected on the plane and each data point is assigned to the closest centroid. Then, an iteration process is carried out to determine the best positions for the centroids:

- the position of the centroid of each cluster is recalculated by taking the mean value of the coordinates of the data points assigned to that cluster,

- if the positions of the centroids did not change, end the iteration,

- $\quad$ if the positions of the centroids changed, assign the data points to the cluster of the closest, newly calculated centroid.

In case of the Euclidean distance, the $k$-means method always converges. However, the exact assignment of data points to clusters can depend on the initial choice of the centroids, therefore several consecutive runs of the clustering algorithm have to be carried out. In our case, 1000 consecutive runs with different starting centroids were done.

Let us denote the distance between data point $x_{i}$ and centroid $c_{j}$, with $d\left(x_{i}, c_{j}\right)$, where $1 \leq j \leq$ $k$. By the nature of the clustering method, the minimum of this function is for the centroid of the cluster of $x_{i}$ :

$$
\min _{j} d\left(x_{i} ; c_{j}\right)
$$

The so-called sum of squared errors (SSE) is calculated as the sum of the squares of the distances of the data points to their respective centroids:

$$
S S E=\sum_{i=1}^{N}\left(\min _{j} d\left(x_{i} ; c_{j}\right)\right)^{2}
$$


where $N$ is the total number of data points. The clustering with the lowest SSE value is chosen to be the valid clustering.

The $k$-means clustering was carried out by using the KMeans_rcpp() function of the ClusterR package [16]

\section{RESULTS AND DISCUSSION}

Without any clustering performed, it can be stated in general that the farther to the right an equipment is on the plane (i.e. closer to the Decision Stick), the more modern it is (see Fig. 4).

\section{Hierarchical clustering}

Performing the hierarchical clustering with the four methods on the data of both the AD and the MF GAIA planes, the same results were obtained. The change in the minimal distance that determines which clusters to merge, shows two steps: one between 2 and 3 clusters and one between 7 and 8 clusters for the Single Linkage, Average Linkage and McQuitty methods (see Fig. 3). There is no significant change in the behavior of the distance measure in case of the Complete Linkage method. This means that there are either 3 or 8 reasonable clusters in the data set. Therefore, the $k$-means clustering was carried out for these two $k$ values.

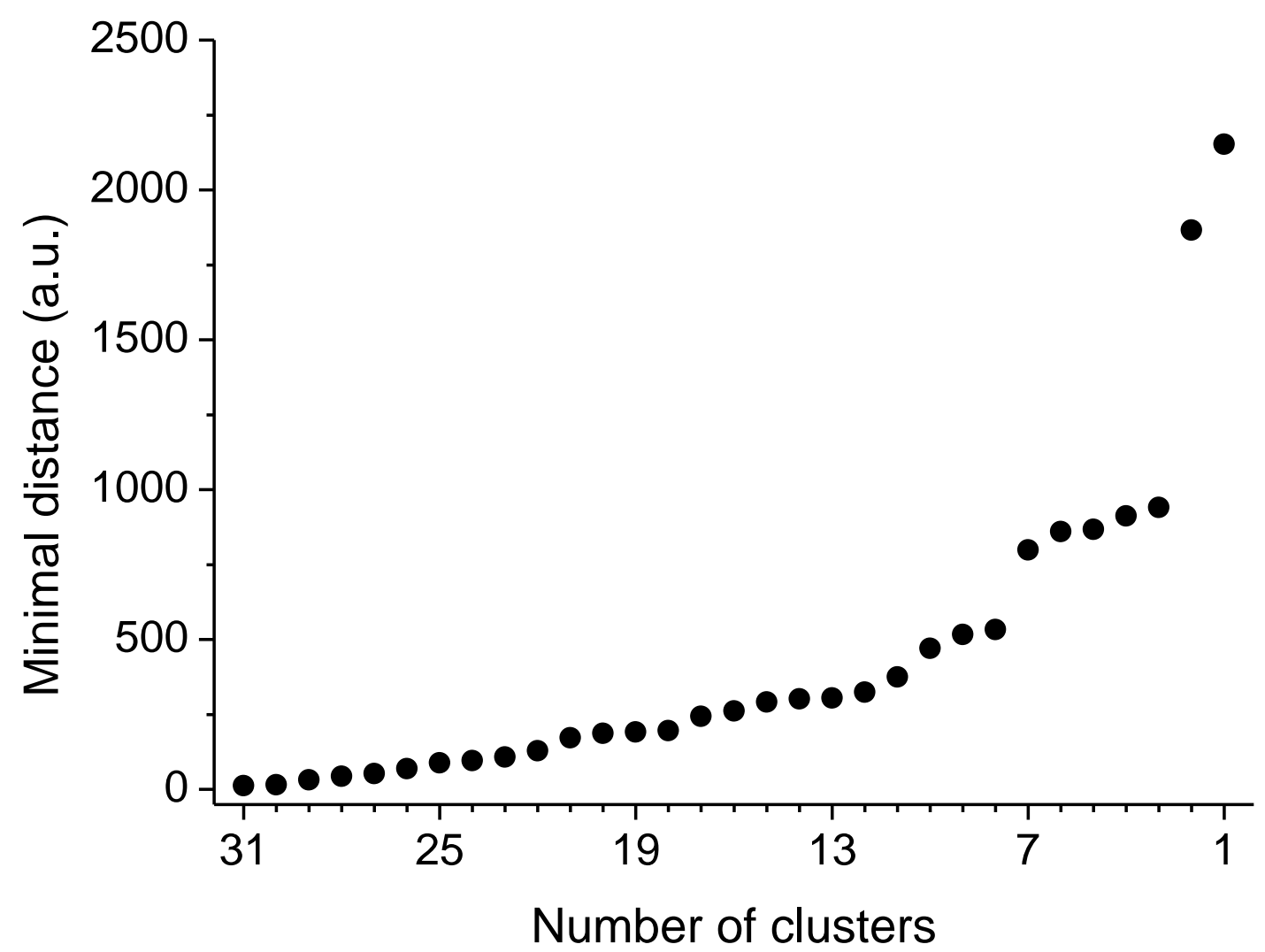

Figure 3. Minimal distance used to merge the last two clusters with the McQuitty method for the MF plane data. The results obtained from the Single Linkage and the Average Linkage methods show the same behaviour. (Made by authors.)

\section{Non-hierarchical clustering}

The results of the $k$-means clustering was the same for the AD and the MF data both for the $k$ $=3$ and the $k=8$ case: the same vehicles were grouped together in both application areas. 
At first sight, the GAIA plane regarding the MF application area differs from the GAIA plane regarding the $\mathrm{AD}$ application area in that the criterion vectors and alternatives are approximately mirrored to the horizontal axis. In fact, this does not have any practical relevance on the clustering because only the relative positions of alternatives and criteria vectors have to be taken into consideration. Since these relative positions are mostly the same in the two application areas, the criteria have similar effects on the alternatives. Regarding the results, not only the similarities but also the differences are important.

\section{Three clusters}

The results of the $k$-means clustering for $k=3$ assumed clusters can be seen in Figure 4 .

Cluster A is the group of the four BTR vehicles, which have the most important distinctive property that they lack the rear hatch.

The distinction between clusters $\mathrm{B}$ and $\mathrm{C}$ can be made on the temporal base: the vehicles grouped together in cluster B were constructed much earlier than the ones in cluster C. All of the ones belonging to cluster B were designed before 2000, while the ones belonging to cluster $\mathrm{C}$ were developed after 2005. The two clusters thus distinguish the vehicles from the 20th and the 21 st century.

The Decision Stick aims at the right side of cluster C, which area contains the group of the alternatives that best satisfy the defense criteria.

These observations are also valid for the respective D, E and F clusters. 
a)

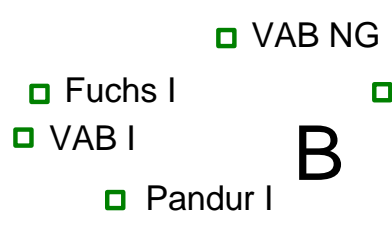

口 Fuchs I

$\square$ VAB I

口 Pandur I

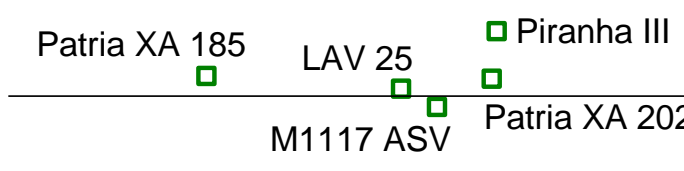

$\Delta$

$$
\begin{aligned}
& \text { BTR } 80 \\
& \Delta \\
& \text { BTR } 80 \text { A }
\end{aligned}
$$

A

$\Delta$

BTR 82A

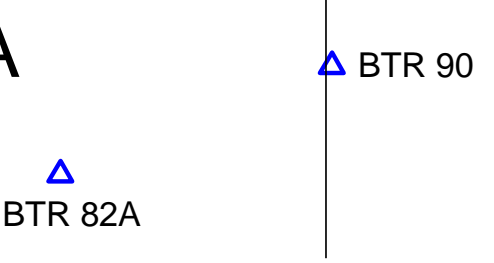

b)

BTR $82 \mathrm{~A}$
$\Delta$

BTR 90

BTR 80A

$\Delta$

BTR 80

$D$

$\Delta$

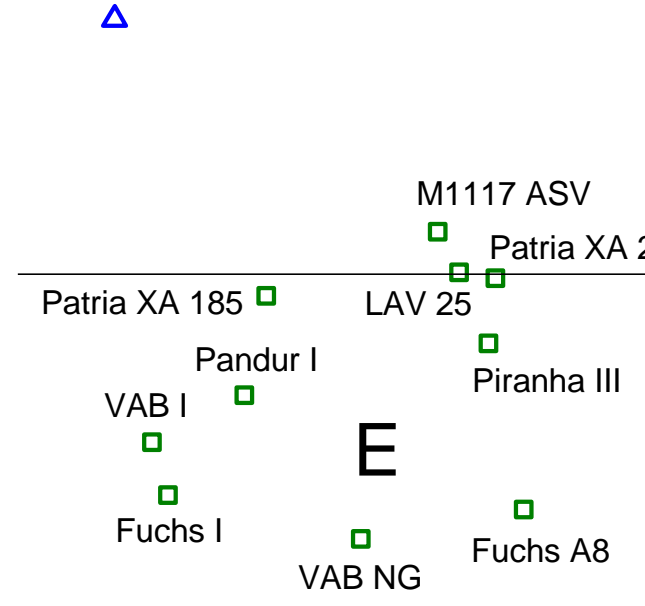

Figure 4. The $k$-means clustering of the data points of the alternatives on the a) $\mathrm{AD}$ and the b) MF planes. The clustering was performed 1000 times with $k=3$. The black vector is the Decision Stick. (Made by authors.) 


\section{Eight clusters}

The results of the $k$-means clustering for $k=8$ assumed clusters can be seen in Figure 5 .

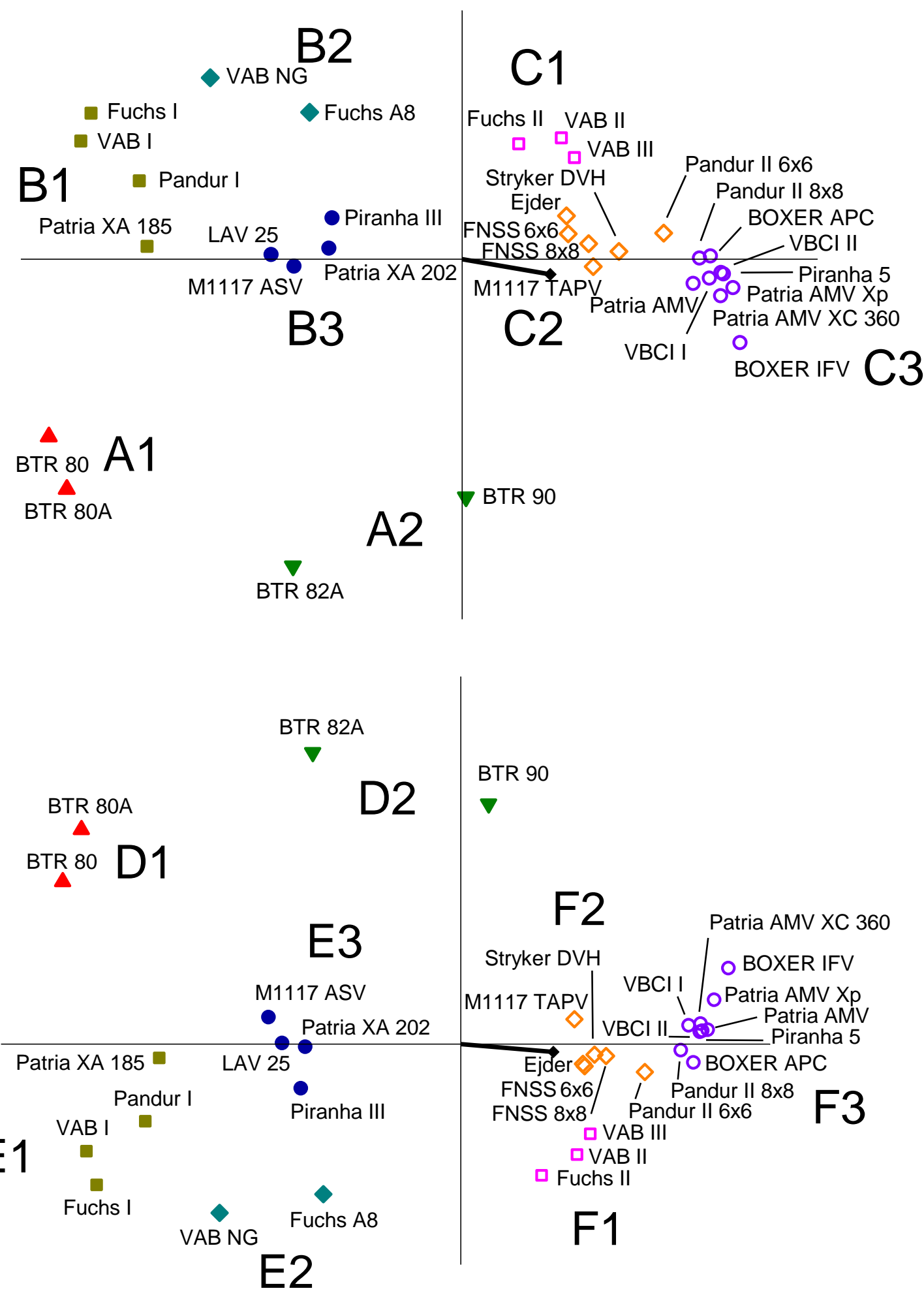

Figure 5. The $k$-means clustering of the data points of the alternatives on the a) $\mathrm{AD}$ and the b) MF planes. The clustering was performed 1000 times with $k=8$. The black vector is the Decision Stick. (Made by authors.) 
In this clustering case, cluster A of Fig.4 splits into two parts. As previously mentioned, clusters $\mathrm{B}$ and $\mathrm{C}$ split on when the cluster members were designed. This is true for clusters A1 and A2: the BTR-82A and BTR-90 are slightly more recent developments, and thus somewhat better constructions than the BTR-80 and BTR-80A, though still far below the present standards.

Assuming eight clusters, cluster B of Fig.4 splits into three. Again, the newer, the better: while the vehicles in the B1 cluster are the equipment of the 1970s and 1980s, the vehicles of cluster B2 are the modernized versions of those and cluster $\mathrm{C} 1$ contains the newest versions of these vehicles. Elements of cluster B3 are better than both B1 and B2, thus their distinction by the clustering algorithm is reasonable: their protection is better in all aspects.

Undoubtedly, cluster C3 is the cluster of the best protected vehicles in the data set. This is obvious from its position: it lies closest to the direction of the Decision Stick of the GAIA plane. The elements of $\mathrm{C} 1$ are slightly inferior to them, mainly because of their construction: since they have less axles, the nominal ground pressure they expose is higher. The separation of cluster C2 can have two reasons: either the vehicle has lower ballistic defense capability, or they are much heavier than the vehicles with similar other aspects in cluster $\mathrm{C} 2$, which is an important criterion in the ranking process. The only exception is the M1117 TAPV, which is well defended and small. It is nicknamed "pitbull", but in this ranking its larger weight and size seems to be a slight disadvantage due to the smaller number of soldiers it can carry. A similar exception in the cluster C2 the Pandur II 6x6 vehicle which could belong to cluster C3, but it has small payload capability.

\section{CONCLUSION}

Based on the data of a Multi Criteria Decision Making model and hierarchical and non-hierarchical clustering, we have shown that the different types of wheeled armored vehicles with similar level of protection tend to group together on the GAIA plane both in the areal defense and abroad mission field application areas.

If the evaluation of a new equipment, based on the same criteria, is carried out and its resulting data point is projected on the two GAIA planes presented, it can be compared to the ones already analyzed. This can provide suggestions regarding which equipment the new one is similar to (as a substitute alternative) or better or worse than the others according to the criteria taken into account.

\section{REFERENCES}

[1] GYARMATI, J.: Napjainkban alkalmazott irányitott páncéltörő rakétarendszerek összehasonlitó elemzése; Katonai Logisztika 20. 3. (2012), pp. 57-72. (in Hungarian), URL:

http://epa.oszk.hu/02700/02735/00073/pdf/EPA02735_katonai_logisztika_2012_3_057072.pdf, last accessed: 11.02.2019.

[2] GYARMATI, J; GÁVAY, Gy.: Presentation of off-road vehicles, selection and analysis; Hadmérnök IX. 1. (2014) pp. 5-15., URL: http://hadmernok.hu/141_01_gavaygy.pdf, last accessed: 11.02.2019.

[3] GYARMATI, J.: Döntési modell kialakitása közbeszerzési eljárás során; Hadmérnök II. 3. (2007), pp. 36-52 (in Hungarian), URL: http://hadmernok.hu/archivum/2007/3/2007_3_gyarmati.pdf, last accessed: 11.02.2019. 
[4] GYARMATI, J.: Haditechnikai eszközök összehasonlitása közbeszerzési eljárás során; Hadmérnök I. 2. (2006), pp. 68-93., URL:

http://hadmernok.hu/archivum/2006/2/2006_2_gyarmati.pdf, last accessed: 11.02.2019.

[5] GYARMATI, J.: Military Application of Multi-Criteria Decision Making; Academic and Applied Research in Military and Public Management Science 14. 4. (2015), pp. 291297., URL: https://folyoiratok.uni-nke.hu/document/uni-nke-hu/aarms-2015-4gyarmati.original.pdf, last accessed: 11.02.2019.

[6] GYARMATI, J.: Haditechnikai eszközök összehasonlitása: útmutató; Zrínyi Miklós Nemzetvédelmi Egyetem, Budapest, Hungary, 2011. (in Hungarian)

[7] GÁVAY, Gy.: Kerekes harcjárművek védettségének vizsgálata és összehasonlító elemzése az elmúlt évtizedek katonai tapasztalatainak és követelményeinek felhasználásával, $\mathrm{PhD}$ thesis, in progress (in Hungarian)

[8] http://paleodb.org/public/summercourse07/olszewski_clustering.pdf, last accessed: 11.02.2019.

[9] GYARMATI, J.; FELHÁZI, S.; KENDE, Gy.: Choosing the Optimal Mortar for an Infantry Battalion's Mortar Battery with Analytic Hierarchy Process using Multivariate Statistics; In: NATO (szerk.) Decision Support Methodologies for Acquisition of Military Equipment, Brussels, Belgium: NATO Research and Technology Organisation (RTO), (2009), pp. 1-12

[10] GYARMATI, J.; VÉG, R. L.; HEGEDÜS, E.; GÁVAY, Gy. V.: A katonai felsőoktatás részvételének lehetőségei a kutatás-fejlesztési folyamatokban; Müszaki Katonai Közlöny XXVIII. 1. (2018), pp. 193-208 (in Hungarian) URL: http://hhk.archiv.uninke.hu/downloads/kiadvanyok/mkk.uni-nke.hu/PDF_2018_1sz/13_Gyarmati-VeghHegedus-Gavay_Oktatas\%20MKK\%20cikk.pdf, last accessed: 11.02.2019.

[11] GÁVAY, Gy.; GYARMATI, J.; HEGEDÜS, E.; VÉG, R. L.: A kutatás fejlesztés szerepe és hatása az oktatásra az NKE HHK Haditechnikai tanszékén, Hadmérnök XII:(4) (2017), pp. 26-33 (in Hungarian), URL: http://hadmernok.hu/174_03 gavay.pdf, last accessed: 11.02.2019.

[12]RAPCSÁK, T.: Többszempontú döntési problémák; Budapesti Corvinus Egyetem, Budapest, Hungary, 2007.

[13] http://www.promethee-gaia.net/software.html, last accessed: 11.02.2019.

[14] http://www.promethee-gaia.net/files/VPManual.pdf, last accessed: 11.02.2019.

[15] $R$ Core Team (2012). $R:$ A language and environment for statistical computing. $R$ Foundation for Statistical Computing, Vienna, Austria. ISBN 3-900051-07-0, URL http://www.R-project.org/

[16] MOUSELIMIS, L.: ClusterR: gaussian mixture models, K-Means, mini-batch-Kmeans and K-Medoids clustering. https://CRAN.R-project.org/package=ClusterR, R package version 1.1 .8 